Out of the Shadow 
THIS PAGE INTENTIONALLY LEFT BLANK 


\title{
Out of the Shadow
}

\author{
REVISITING THE REVOLUTION \\ FROM POST-PEACE GUATEMALA
}

Edited by Julie Gibbings and Heather Vrana

University of Texas Press $\mathbf{v}$ Texas 
Copyright (C) 2020 by the University of Texas Press

All rights reserved

Printed in the United States of America

First edition, 2020

Requests for permission to reproduce material from this work should be sent to: Permissions

University of Texas Press

P.O. Box 7819

Austin, TX 78713-7819

utpress.utexas.edu/rp-form

@ The paper used in this book meets the minimum requirements of ANSI/NISO Z39.48-1992 (R1997) (Permanence of Paper).

Library of Congress Cataloging-in-Publication Data

Names: Gibbings, Julie, editor. | Vrana, Heather A., editor.

Title: Out of the shadow : revisiting the revolution from post-peace Guatemala / edited by Julie Gibbings, Heather Vrana.

Other titles: Revisiting the revolution from post-peace Guatemala

Description: First edition. | Austin, TX: University of Texas Press, [2020] | Includes bibliographical references and index.

Identifiers: LCCN 2019040184 | ISBN 978-1-4773-2085-3 (cloth) | ISBN 978-1-4773-2086-0 (library ebook) | ISBN 978-1-4773-2087-7 (ebook)

Subjects: LCSH: GuatemalaPolitics and government1945-1985.

| GuatemalaHistoryRevolution, 1954Influence. | Social changeGuatemalaHistory20th century. | MayasGuatemalaSocial conditions. | Ethnic conflictGuatemala. | GuatemalaHistory1945-1985. | Collective memoryGuatemala.

Classification: LCC F1466.5 .O83 2020 | DDC 972.8105/2dc23

LC record available at https://lccn.loc.gov/2019040184

doi: $10.7560 / 320853$ 
To the Guatemalan revolutionaries of 1944-1954 and all other generations who drew and will draw inspiration from them 
THIS PAGE INTENTIONALLY LEFT BLANK 